\title{
PRINCIPLES OF JUSTICE, CONFERENCE AND LEGAL ACCOUNTABILITY IN DIVORCE RULES
}

\author{
Masri Olii \\ Islamic Law Study Program Student, Concentration of Islamic Family Law \\ UIN Sunan Gunung Djati Bandung \\ Email: masri.olii@yahoo.co.id
}

\begin{abstract}
The Religious Courts, in the last decade (since 2005) or since the implementation of the one roof system of judiciary, have made various improvements in the administration of justice to support efforts to reform the judiciary based on the principles of transparency and accessibility for all. the justice seeker. The Religious Courts are trying to reform several sub-systems in the judicial system that have so far not reflected equal access for justice seekers as well as protection or partiality for the rights and legal access of women, children, and the poor. The results of this study indicate that: the religious court is a place to seek justice and resolve Islamic family law problems, so in providing services to the community, it has the main task of providing fair and humane treatment to justice seekers, providing sympathetic services and assistance needed for justice seekers, and provide effective, efficient, thorough and final settlement of cases so as to satisfy the public.
\end{abstract}

Keywords: Religious Courts, Justice, Poor, women, children, legal, the rights.

\section{A. INTRODUCTION}

Normatively, the court is a place to get justice. Meanwhile, the verdict is the crown issued by the judge as the enforcer of law and justice. In the framework and efforts to find and implement justice the judge's decision must have objectives, namely first, it must be an authoritative solution meaning that it can provide solutions to legal problems faced by the parties; second, it must contain efficiency, meaning that it is easy, fast, and low cost; third, it must be in accordance with the objectives of the law which is the basis for court decisions; fourth, it must contain aspects of stability, namely social order and public order; and fifth, the judge's decision must have fairness, that is, to provide equal opportunities to the parties in a case (Alkostar, 2019).

Departing from the reality that many PA judges in adjudicating a case are too fixated on the legal text, so that judges prioritize the principle of legal normativity rather than the obligation to uphold justice. The perspective that standardizes this legal text, according to Satjipto Rahardjo, will have implications for failure and sterilization of the function of the law itself (Rahardjo, $2016: 4,16,57$, 11 and 92). Because in law enforcement, according to Satjipto Rahardjo, law must be realized to serve humans in creating a more orderly and problematic life.

The Religious Courts as one of the executors of judicial power are faced with two big expectations. First, the Religious Courts are required to uphold law and justice as well as possible. The Religious Courts are required to apply the law in concreto cases by paying attention to relevant and decisive facts. On this side, the Religious Courts are required to implement normative aspects of law. Second, the Religious Courts are also required to pay more serious attention to the interests of women and children who are "generally" victims of disputes that occur within the sphere of the family. Religious Court judges are required to have extraordinary discernment and sensitivity to the suffering faced by women and children who are victims of the behavior of their husbands / fathers who have neglected their responsibilities. It is hoped that the 
decisions that arise from these cases are able to provide quick and appropriate solutions for women and children.

In response to this, the Supreme Court has issued Supreme Court Regulation Number 3 of 2017 concerning Guidelines for Adjudicating Cases of Women in Confrontation with the Law (Perma). This regulation is motivated by the desire of the Supreme Court to remove obstacles for women in gaining access to justice and to free women from all forms of discrimination in the justice system.

This desire is in line with the development of contemporary legal thought which calls for equal rights and access for women before the law (equal right before the law) voiced by exponents of feminist legal theory (Levit \& Verchick, 2016). Law, should not be perceived as a territory or domain of male power. Hegemonic masculinity of law should be abandoned and turned to egalitarian laws that place men and women in an equal position.

The theory above seems relevant to the theory of maqasid al-sharia which requires the realization of benefit as the goal of Islamic law. The realization of justice must be the main mission in upholding the law so that we must not ignore the context that surrounds it. Likewise, if the theory is linked to the theories in the Islamic judiciary, Ibn Qayyim emphasized that the judges are obliged to escape from adultery, static attitudes, be bound by certain ideas and others. For the sake of humanity, they have to put forward the new developments which are indispensable in the form of rules of law. After that, they must choose justice. They must realize that justice is the law of Allah. Therefore, they are obliged to accept indications and implications that can bring them closer to justice (Al-Jauziyah, 2006 : xvii).

Regarding acting fairly, Allah SWT has said in Surah an-Nahl Verse 90 :

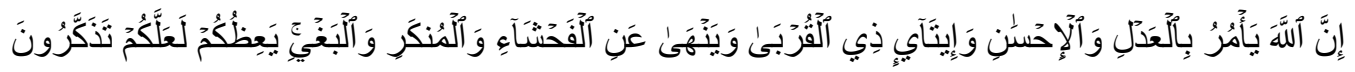

Indeed, Allah commands (you) to be fair and do good, to give to relatives, and Allah forbids from abominable acts, evil and enmity. He teaches you so that you can take lessons.

The Religious Courts, in the last decade (since 2005) or since the implementation of the one roof system of judiciary, have made various improvements in the administration of justice to support efforts to reform the judiciary based on the principles of transparency and accessibility for all. the justice seeker. The Religious Courts are trying to reform several sub-systems in the judicial system which have not been considered to have reflected equal access for justice seekers and protection or partiality for the rights and legal access of women, children, and the poor.

Given the importance of the principles of justice, legal certainty and benefit in the decisions handed down by judges as a court product, the author feels the need to describe how a decision has these three aspects so that the decision of the justice-seeking community does not feel neglected.

To answer the problems in this study, the authors use several theories including: Grand Theory (Theory of Justice and Legal Benefits), Middle Theory (Maslahah al-Mursalah Theory) Application Theory (Theory of Judges' Judgments). 


\section{B. RESEARCH METHOD}

In this study, the authors took the type of qualitative data. Qualitative data is data in the form of words and actions. Qualitative data is data in the form of words, sentences, gestures, facial expressions, charts, pictures and photos. Qualitative research data does not use population, because qualitative research departs from certain cases in certain social situations and the results of the study are applied to the population, but transferred to other places in social situations that have similarities to the social situation in the cases studied. Samples in qualitative research are not called respondents, but sources, participants, informants, in the study. The research sample in qualitative research is also not called a statistical sample, but a theoretical sample, because the purpose of qualitative research is to produce a theory.

\section{RESULT AND DISCUSSION}

The Religious Court is one of the judicial bodies that carries out the tasks given by law and is given the power to receive, examine, adjudicate, and resolve civil cases which are specifically for people who are Muslim or who submit to Islamic law voluntarily as stated in articles 49 to Article 53 of Law Number 7 of 1989 jo. Law Number 3 of 2006 jo. Law Number 50 of 2009 concerning Religious Courts.

Normatively, the court is a place to get justice. Meanwhile, the verdict is the crown issued by the judge as the enforcer of law and justice. In order and efforts to find and implement justice, judicial decisions must have objectives, namely first, they must be an authoritative solution, meaning that they can provide solutions to legal problems faced by the parties; second, it must contain efficiency, meaning that it is easy, fast, and low cost; third, it must be in accordance with the objectives of the law which is the basis for court decisions; fourth, it must contain aspects of stability, namely social order and community order; and fifth, the judge's decision must have fairness, that is, to provide equal opportunities to the parties in a case (Alkostar, 2019).

A court decision is considered good if it gives a sense of justice to the parties in a case, to get a good decision it must be handled by a professional judge and a progressive spirit so that in applying legal considerations it can keep up with the times, this is in accordance with the words of legal experts from the Netherlands. , Taverne, he said that: "give me good judges and prosecutors, then even with bad rules I can make good decisions". Taverne's words reflect that the goodness of a judge's decision does not depend on the goodness of the rules that are made. He wanted to state that even if laws and regulations are good and perfect, if they are implemented by people who behave badly, the results will be bad and disappoint many parties. Thus the judge's decision not only has a juridical value (legal certainty), but has a sociological value (usefulness) and a philosophical value (justice).

The courts of first instance are judex factie courts faced directly with concrete cases. In "hard cases", judges often have to make "breakthroughs" in dealing with textual limitations presented in legal sources, especially the Prevailing Laws. Judges are demanded not only to become lawyers, mouthpieces of laws, but more than that, they must have a critical, creative perspective and have the courage to carry out "fresh judgment", participate in creating law (judge made law) to bring law closer to justice. This is where a judge's control of legal discovery is needed (Komisi Yudisial Republik Indonesia, 2014 : 126). 
Basically, in civil law, the judge's duty is to maintain the civil legal system and determine what has been determined in the applicable legal system. On the other hand, the duty of judges in dealing with cases is to be able to resolve a case being faced with a fair decision (Soepomo, 2006 : 13). Meanwhile, the concept of justice in civil law that is carried out in court is the minority given by the judge during the trial until the decision is made by the judge (Butarbutar, 2009 : 386).

Decisions made by judges must basically reflect and be able to voice the conscience of the people. The judiciary is not only a machine of the Law but must be able to observe the life that occurs in society intensively (Wantu, $2012:$ 428). Thus, the judge's decision must continue to measure the elements, namely justice, benefit and legal certainty. This is in line with the opinion of Sudikno Mertokusumo who explained that the parties who litigate in court in upholding the law must pay attention to three elements, namely juridical (legal certainty), sociological (usefulness) and philosophical (justice) (Sulardi, $2015: 258$ ).

Judges are required to better understand the social character of the people in the area so that judges can easily carry out their duties to try cases that need a complete, thorough, detailed and specific exploration. That way, judges are not only textual who only refer to the norms written in the Law. However, judges are required to make breakthroughs in finding laws by collaborating written law with laws that live in the community in a certain area. Thus the court will become a place to guard and protect the community in terms of law enforcement.

The strategy carried out by judges when examining and proving uses a cycological approach, judges do not press, are accommodating, give equal rights in front of the trial, use more subtle words, use a persuasive approach with local wisdom, in sensitive words the judge uses figurative words accepted by the public, the judge was careful in speaking so as not to offend (choosing the right words), saw the social conditions of the parties, advised the parties, and explored clearly and in detail.

The methodological pattern of implementing the principles of justice, benefit and legal certainty in divorce cases in the Religious Courts of the PTA West Java region must be in accordance with the ideals of the law. The emphasis in the methodological pattern in this study is on the formation of judges' decisions that contain principles in legal objectives, namely reflecting the principles of justice, benefit and legal certainty proportionally. Of course in the implementation it becomes a problem for the judge in collaborating the three principles in the form of a decision.

The teaching that discusses the ideals of law (idee des Recht) states that there are three elements of legal ideals that must exist proportionally, namely legal certainty (rechtssicrherkeit), justice (gerechtingkeit), and benefits (zweckmasigkeit), this is what is conveyed in the theory of objectives Gustav Radbruch's law states in the idee des Recht that law enforcement must accommodate these three principles (Wantu, $2007: 388$ ).

In deciding a case, basically the judge must carry out the three principles contained in the theory of legal objectives in compromise, in the sense of applying all three proportionally. However, the judge certainly has an emphasis on one aspect in deciding the case. Because these three principles are complementary and contradictory, but justice is the most important value (Rahmah, 2013 : 303). However, there is no penalty that makes everyone feel satisfied, but what can be done is to punish someone based on a limitative standard of justice, by paying attention to 
instruments both in the form of legal facts and the concept of law and legislation (Jurdi, 2017 : 35-36).

The pattern methodology developed by judges when dealing with cases in the West Java Religious Court, by polarizing the principles of justice, benefit and legal certainty. In every case that comes to the Religious Court the judge may not refuse and the case must be decided. Because every decision made by a judge is certain and certainly contains legal certainty. In the Religious Courts, the priority theory of casuism is used, namely the theory in the application of the principles of legal objectives including justice, benefit and legal certainty in an order of priority, proportionally according to the cases faced and resolved. From various civil cases it can be concluded that a judge in examining and deciding a case is not always fixated on one principle alone because this requires legal consideration using good reasoning (Hartini, 2009 : 383).

To see further, the first pattern method used by judges at the West Java Religious Court in resolving cases is explained as follows:

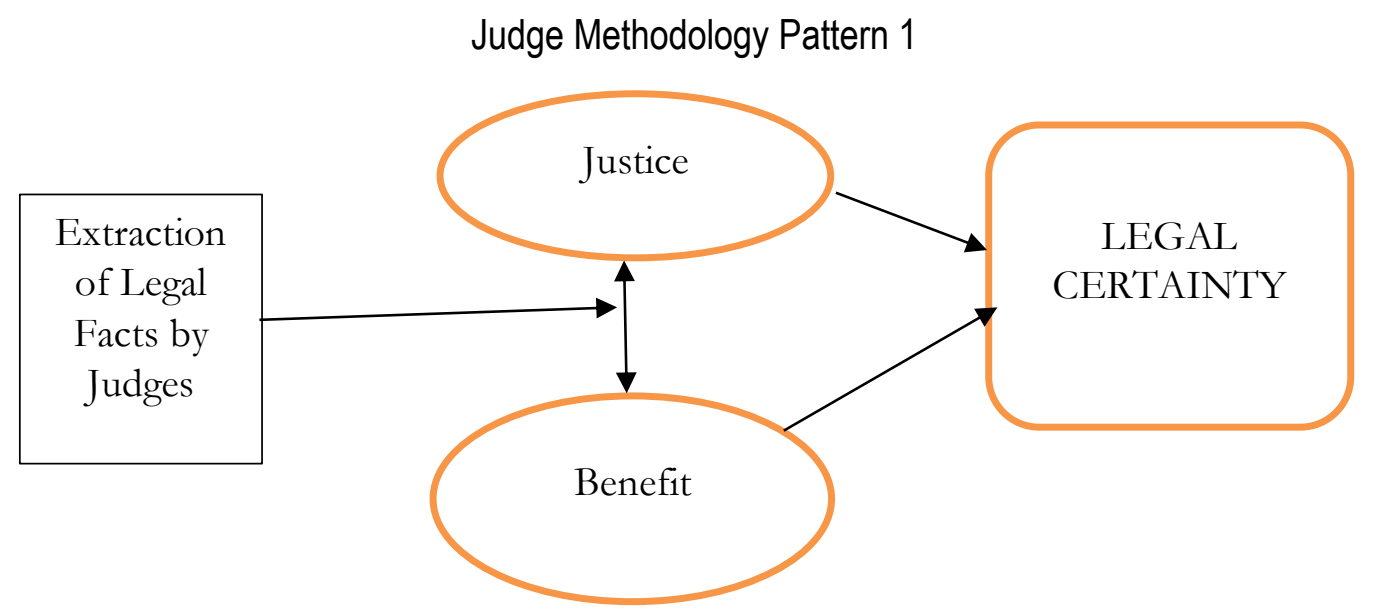

The method that must be used by judges in solving problems faced in a case at trial is extracting legal facts by the judge. The legal facts excavation carried out by the judge is in the process of the legal procedure in the examination and evidence process. Because the process is a very important process in seeking material truth to be used as a reference for judges in making decisions. So judges are in the process of extracting legal facts, digging in detail, clearly, and in depth regarding the problems that are being prosecuted in court. Exploration of legal facts by the judge is necessary, because it will affect the formation of the judge's argument which will be linked to the relevant legal rules.

Seeing the first pattern in legal theory shows that in its formation the judge collaborates the three principles, namely justice, benefit and legal certainty. If it is related to the theory of legal objectives, the first pattern method uses a mixed theory that mixes the theory of ethical law with utility. This is a middle way to emphasize a legal goal which is not only the element of justice but also the benefit for all humans. On the other hand, to regulate order and peace in society, it is necessary to balance the interests of one another so that the rights of everyone are maintained. As the conclusion from Van Kan in his book Inleiding Tot de Rechtwetenscap describes the purpose of law, it is concluded that the purpose of law has a duty to ensure legal certainty in society. So that judges in solving cases in court have the task of finding the right law.

\section{Judge Methodology Pattern 2}




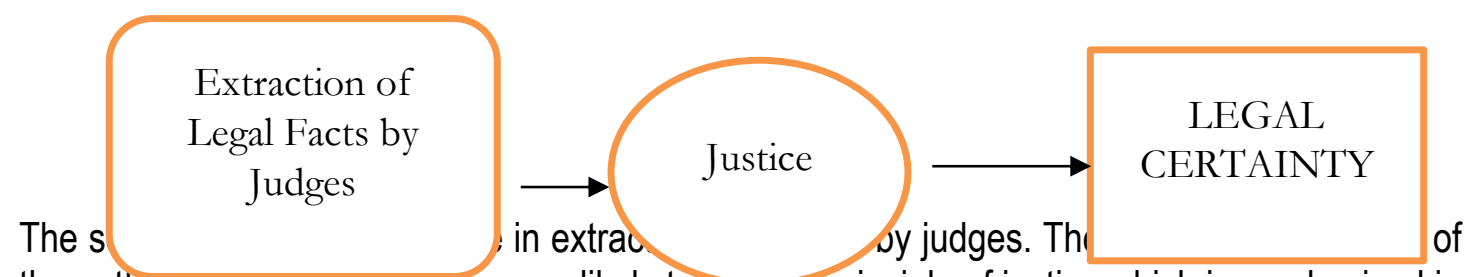

the pattern, une iwo juages are more likely to usc ule principle of justice which is emphasized in the formation of decisions. If you look at the theory of ethical law objectives. Basically, the theory of the objective of ethical law teaches that law is solely formed to achieve justice. This is a form of joint consequence of the agreed law that must provide a sense of justice, provide a sense of trust, and the law must be applied fairly for all elements of society (Hamdani, $1992: 209$ ).

In essence, justice is an assessment of an action by studying a norm which, according to a subjective view, exceeds other norms (Wantu, $2007: 485$ ). If we look at the law enforcement process, judges have the duty to uphold justice (Wantu, 2012 : 484). As a way of achieving legal objectives, the law must be enforced as fairly as possible so that the community is protected by the protection of the law. Fulfillment of philosophical values can be carried out in the application of law in the community. Thus justice as something that is very important to protect every human right from forms of discrimination and injustice.

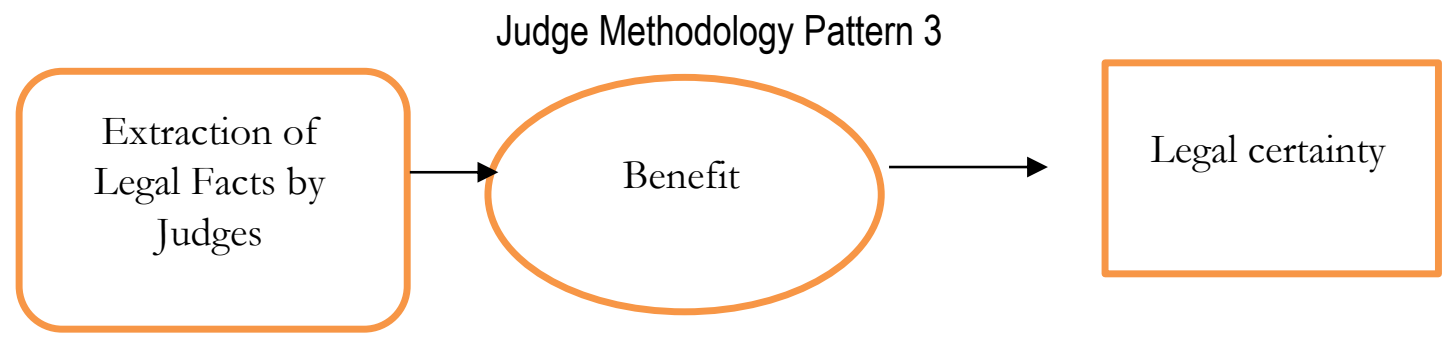

The third methodological pattern used by judges in solving problems in the Religious Courts is of course still the same as seeing the cases at hand, in the third methodological pattern emphasizes the value of benefit in deciding cases. In this pattern using the objective theory of utility law. In this theory, the focus is on the subuah the goal of the law which can provide as much benefit as possible for everyone. It is in line with what Jeremy Betham said that the purpose of a law is merely what is beneficial or beneficial to people.

Of course this will rule out concrete things. So that what will happen can override other elements or principles. In fact, law has an important role as an instrument to provide benefits to society in a holistic manner (Adam, 2020 : 15). So that in the context of law enforcement by judges in judging it is not enough in law alone, because it does not regulate clearly and completely, so judges have to explore legal values that live in society (Muqoddas, $2002: 21$ ).

It is necessary to know that the construction built by the judge in forming a decision consists of the head of the decision which in this case begins with the sentence Bismillah and For Justice Based on Almighty Godhead, is a condition that must be in the decision. This is followed by a clear identity of the parties for the examination of the judge. Followed by a sit-down case, which explains the disputed case, clearly and in detail.

Sitting in the case is used as a reference by the judge in extracting the material truth or legal facts that occurred between the parties. From the point of sitting of the case, the judge performs legal fact excavation by answering answers, examining witnesses and evidence. If in the case 
there is a counterclaim or counterclaim then it will also be described in the sit-down case which will be explained in the form of a counterclaim disclosure. Then proceed with the reasons and the basis for the judge's decision in the trial.

In the legal considerations carried out by the judges of the Religious Court, it contains the relevant regulations both in the rules of the state and the rules of syara 'in the form of the arguments of the Al-Qur'an, hadith and related books. Followed by a decision regarding the subject matter of the dispute to be decided by the judge. After the main decision of the case in the verdict, it is followed by the signature of the judge who tried it and the clerk of the court. And under the signature, the pretext of court fee and the amount is presented.

\section{E. CONCLUSION}

The religious court is a place to seek justice and resolve Islamic family law problems, so in providing services to the community, it has the main task of providing fair and humane treatment to justice seekers, providing sympathetic services and assistance needed for justice seekers, and providing solutions. the case is effective, efficient, thorough and final so that it satisfies the public.

\section{References}

Adam, P. (2020). Hukum Islam: Sejarah, Perkembangan, dan Implementasinya di Indonesia (Buku 2). Sinar Grafika.

Al-Jauziyah, I. Q. (2006). Al-Turuq al-Hukmiyyah fi al-Siyasah al- Syar'iyyah-Hukum Acara peradilan Islam (A. Qihar, Trans.). Pustaka Pelajar.

Alkostar, A. (2019). Menegakan Hukum Pidana. Mahkamah Agung. https:/l www.mahkamahagung.go.id/images/uploaded/15f.MENEGAKKAN_HUKUM_PIDANA. pdf.

Butarbutar, E. N. (2009). Konsep Keadilan Dalam Hukum Perdata. Mimbar Hukum, 12.

Hamdani, N. (1992). Teori Tujuan Hukum. Gramedia.

Hartini. (2009). Pengecualian terhadap Penerapan Asas Ultra Petitum Partium dalam Beracara di Pengadilan Agama. Mimbar Hukum, 21(2).

Jurdi, F. (2017). Logika Hukum. Prenadamedia Group.

Komisi Yudisial Republik Indonesia. (2014). Problematika hakim dalam konteks hukum, pengadilan dan kemasyarakatan di Indonesia: Studi sosio-legal. Sekretariat Jendral Komisi Yudisial Republik Indonesia.

Levit, N., \& Verchick, R. R. M. (2016). Feminist Legal Theory. NYU Press.

Muqoddas, B. (2002). Mengkritik Asas-Asas Hukum Acara Perdata. Jurnal Hukum, 9(20).

Rahardjo, S. (2016). Sisi-sisi Lain dari Hukum di Indonesia. Kompas.

Rahmah, A. M. (2013). Hermeneutika Hukum Sebagai Alternatif Metode Penemua Hukum Bagi Hakim Untuk Menunjang Keadilan Gender. Jurnal DInamika Hukum, 13(2).

Soepomo, R. (2006). Hukum Acara Perdata. Pradnya Pramita.

Sulardi. (2015). Kepastian Hukum, Kemanfaatan, Dan Keadilan Terhadap Perkara Anak Kajian Putusan Nomormor. 201/Pid.Sus/2014/PN Blt. Jurnal Yudisial, 8(3).

Wantu, F. M. (2007). Antinomi Penegakan Hukum Oleh Hakim. Mimbar Hukum, 19(3).

Wantu, F. M. (2012). Mewujudkan Kepastian Hukum, Keadilan Dan Kemanfaatn Dalam Putusan Hakim Diperadilan Perdata. Jurnal DInamika Hukum, 12(3). 